\title{
ANALISIS PEMECAHAN MASALAH SISWA DALAM MENYELESAIKAN SOAL TINGKAT RENDAH PADA MATERI GEOMETRI
}

\author{
Faradiba Jabnabillah \\ Fakultas Teknologi Informasi, Institut Teknologi Batam, \\ Jl. Gajah Mada Kompleks Vitka City, Tiban Ayu - Sekupang - Batam \\ Email : faradiba@iteba.ac.id
}

\begin{abstract}
This research aims at exploring and describing students' problem solving in answering questions related to factual, conceptual, and procedural dimension. This research uses descriptive qualitative approach. The subjects selected in this research are based on their mathematics ability level; there are high ability, intermediate ability, and the low ability. The accuracy and validity in this research are obtained by using test and interview as the instruments. The technique of data analysis in this research is descriptive qualitative. The research findings show that students' problem solving in questions related to factual dimension indicates the answers from the students who have high, intermediate, and low ability are almost in all indicators. However, it does not apply in the indicator of checking the answers. Meanwhile, students' problem solving in questions related to conceptual dimension shows the answers from the students who have high, intermediate, and low ability can fulfil all indicators. The last, students' problem solving in questions related to procedural dimension shows that the answers from the students who have high, intermediate, and low ability cannot fulfil some indicators such as the indicator of answering questions, and checking the answers.
\end{abstract}

Keywords: Problem Solving, Factual Dimension, Conceptual Dimension, Procedural

\section{Dimension}

\begin{abstract}
Abstrak
Penelitian ini bertujuan untuk mengeksporasi dan mendeskripsikan pemecahan masalah siswa dalam menyelesaikan soal pada dimensi pengetahuan faktual, konseptual dan prosedural. Penelitian ini menggunakan pendekatan kualitatif yang bersifat deskriptif. Subjek yang dipilih dalam penelitian ini berdasarkan tingkat kemampuan matematika yaitu tinggi, sedang dan rendah. Akurasi data yang valid dalam penelitian ini diperoleh menggunakan instrumen tes dan wawancara. Teknik analisis data dalam penelitian ini menggunakan teknik analisis deskriptif kualitatif. Hasil penelitian pada pemecahan masalah siswa pada soal faktual menunjukkan jawaban siswa yang berkemampuan tinggi, sedang dan rendah memenuhi hampir seluruh indikator kecuali indikator memeriksa kembali jawaban; pemecahan masalah siswa berkemampuan tinggi, sedang dan rendah pada soal konseptual memenuhi seluruh indikator; pemecahan masalah siswa berkemampuan tinggi, sedang dan rendah pada soal prosedural tidak memenuhi beberapa indikator seperti pada indikator menyelesaikan soal dan indikator memeriksa kembali jawaban.
\end{abstract}

Kata kunci: Pemecahan Masalah, Faktual, Fonseptual, Prosedural 


\section{PENDAHULUAN}

Pemecahan masalah merupakan suatu dorongan bagi siswa untuk melakukan proses dan strategi dalam menyelesaikan suatu masalah yang diberikan, hal ini menjadikan pemecahan masalah sebagi proses inti dan utama dalam pembelajaran (Fatmawati, Mardiyana \& Triyanto, 2014; Hidayat \& Ratna, 2018). Pemecahan masalah dan matematika dalam kurikulum 2013 merupakan dua komponen yang saling terkait karena pemecahan masalah merupakan aktivitas dalam pembelajaran matematika dan sebagai standar kompetensi yang harus dimiliki siswa (Haryani, 2012; Kemendikbud, 2013; Nursyahidah, dkk, 2018).

Pada proses pemecahan masalah untuk mencari dan menemukan solusi pada masalah matematika membuat individu untuk berpikir dan mencoba menemukan solusinya dan pada tahap ini berpikir dimulai (Ersoy \& Guner, 2012). Sehingga dalam hal ini ketika kita berbicara tentang pemecahan masalah maka erat sekali kaitannya dengan berpikir matematika, karena menurut Das \& Das (2013) bahwa pemecahan masalah pada bidang matematika dapat meningkatkan kemampuan berpikir, menerapkan prosedur dan memperdalam pemahaman konseptual siswa.

Pada proses berpikir memiliki beberapa kategori, Bloom (1956) menyatakan bahwa dimensi kognitif sebagaimana pengembangan dari proses berpikir tingkat tinggi dibedakan menjadi empat kategori yaitu: faktual, konseptual, prosedural dan metakognitif. Akantetapi pada penelitian ini hanya akan membahas pemecahan masalah siswa yang difokuskan pada kemampuan berpikir matematika tingkat rendah yaitu pada aspek kognitif dimensi pengetahuan faktual, konseptual dan prosedural. Hal ini karena persentase pencapaian keberhasilan siswa Indonesia dalam menyelesaikan soal-soal UAN matematika masih rendah yaitu sebesar $44,05 \%$ pada tahun 2018 dan 46,56\% pada tahun 2019 (Kemendikbud, 2019). Padahal soal-soal UAN yang diberikan lebih mendominasi pada soalsoal dimensi pengetahuan tingkat rendah (Desvika \& Budiyono, 2015; Marzuqi, Sugiarti \& Setiawan, 2015). Adapun indikator proses pemecahan masalah siswa menurut Polya (1973) yang akan digunakan dalam penelitian ini adalah:

\section{Tabel 1.1 Indikator Proses Pemecahan Masalah}

\begin{tabular}{|c|c|}
\hline $\begin{array}{c}\text { Tahapan } \\
\text { Pemecahan } \\
\text { Masalah Polya }\end{array}$ & Indikator \\
\hline $\begin{array}{l}\text { 1. Memahami } \\
\text { masalah }\end{array}$ & $\begin{array}{l}\text { a. Siswa memahami } \\
\text { informasi yang ada } \\
\text { (apa yang diketahui) } \\
\text { b. Siswa menentukan } \\
\text { apa yang ditanyakan }\end{array}$ \\
\hline $\begin{array}{l}\text { 2. Membuat } \\
\text { rencana } \\
\text { pemecahan } \\
\text { masalah }\end{array}$ & $\begin{array}{l}\text { a. Siswa membuat } \\
\text { pemisalan } \\
\text { b. Siswa membuat } \\
\text { model matematika }\end{array}$ \\
\hline $\begin{array}{l}\text { 3. Melaksanakan } \\
\text { rencana } \\
\text { pemecahan } \\
\text { masalah }\end{array}$ & 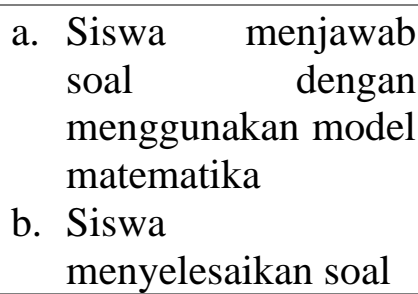 \\
\hline $\begin{array}{l}\text { 4. Memeriksa } \\
\text { kembali }\end{array}$ & $\begin{array}{l}\text { Siswa memeriksa } \\
\text { kembali jawaban yang } \\
\text { dikerjakan }\end{array}$ \\
\hline
\end{tabular}

Pada penelitian ini berfokus pada materi geometri karena konsep yang termuat di dalam pembelajaran geometri menempatkan materi 
geometri dalam proporsi yang relatif banyak dalam kurikulum. Pada tingkatan Sekolah Menengah Pertama (SMP), sekitar $42 \%$ materi yang diajarkan berupa materi geometri. Ada dua dari enam standar kompetensi yang berisikan materi geometri untuk kelas VII dan ada tiga dari lima standar kompetensi yang berisikan materi geometri untuk kelas VIII (Oktorizal, Elniati \& Suherman, 2012). Melihat materi geometri lebih dominan diajarkan kepada siswa, sehingga lebih banyak mencakup aspek kognitif pada dimensi pengetahuan faktual, konseptual dan prosedural. Hal tersebut menjadi alasan peneliti mengambil materi geometri untuk meneliti proses pemecahan masalah siswa dalam menyelesaikan soal kognitif tingkat rendah.

Berdasarkan hasil pengamatan di MTs NU TMI Pujon, proses pembelajaran yang dilakukan guru di sekolah berfokus pada penyerapan konten pelajaran melalui cara menghafal, bukan pada proses berpikirnya. Sementara itu, berdasarkan hasil UAN matematika di MTs NU TMI Pujon pada tahun 2016 banyak siswa yang mendapatkan nilai di bawah rata-rata yaitu sebesar $37,18 \%$. Hal ini sejalan dengan pernyataan Syaiful (2012) bahwa rendahnya prestasi siswa disebabkan karena lemahnya proses pembelajaran di Indonesia. Pada proses pembelajaran siswa terbiasa menghafal dan menerima informasi yang diberikan, tanpa didorong untuk mengembangkan kemampuan berpikir siswa, sehingga siswa kurang memahami informasi yang diterimanya. Pernyataan ini diperkuat oleh Permanasari (2013) bahwa dalam proses pembelajaran matematika masih dinilai kurang maksimal, sehingga siswa kurang terlatih dalam menyelesaikan soal yang kontekstual dan menuntut untuk berpikir dari tingkat rendah hingga tinggi. Sehingga dari sinilah peneliti tertarik untuk melihat bagaimana kemampuan berpikir matematis siswa kelas
VIII MTs NU TMI Pujon pada soal-soal faktual, konseptual dan prosedural.

Adapun tujuan dalam penelitian ini adalah untuk: (1) mengeksplorasi pemecahan masalah siswa dalam menyelesaikan soal faktual, (2) mengeksplorasi pemecahan masalah siswa dalam menyelesaikan soal konseptual, dan (3) mengeksplorasi pemecahan masalah siswa dalam menyelesaikan soal prosedural.

\section{METODE PENELITIAN}

Penelitian ini menggunakan pendekatan kualitatif dengan jenis penelitian deskriptif. Penelitian ini dilakukan di MTs NU TMI Pujon. Subjek dalam penelitian ini adalah siswa kelas VIII, kemudian peneliti memilih 3 subjek dari jumlah siswa secara keseluruhan dalam satu kelas yang berkemampuan tinggi yang disimbolkan dengan $(\mathrm{T})$, sedang $(\mathrm{S})$ dan rendah (R). Data dikumpulkan dengan menggunakan tes dan wawancara. Hasil pengerjaan siswa pada lembar tes untuk menentukan siswa yang berkemampuan tinggi, sedang dan rendah, serta untuk menentukan pemecahan masalah siswa pada soal faktual, konseptual dan prosedural. Sedangkan hasil wawancara dalam bentuk klarifikasi dari jawaban tertulis.

\section{HASIL DAN PEMBAHASAN}

Hasil tes dan wawancara subjek pada pemecahan masalah yang dianalisis dalam menyelesaikan soal pada aspek kognitif Taksonomi Bloom yaitu pada dimensi pengetahuan faktual, konseptual dan prosedural dijelaskan secara naratif. Adapun hasil tes dan wawancara pemecahan masalah subjek pada dimensi pengetahuan faktual untuk siswa $\mathrm{T}$ dijelaskan pada Gambar 1 sebagai berikut: 


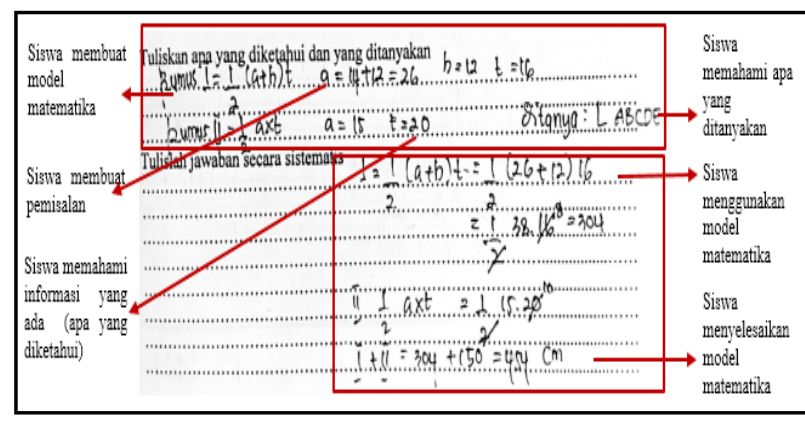

Gambar 1. Jawaban Siswa T Pada Soal Faktual

Pada gambar di atas menunjukkan jawaban siswa $\mathrm{T}$ dalam menjawab soal kemampuan kognitif dimensi pengetahuan faktual pada materi luas bangun datar. Pada indikator memahami informasi yang ada siswa menuliskan bangun yang pertama sebagai trapesium dengan yang diketahui jumlah sisi sejajar yaitu $\mathrm{a}=14+12, \mathrm{~b}=12$ dan $t=16$. Sedangkan untuk bangun yang kedua yaitu segitiga siswa menuliskan yang diketahui yaitu $a=15$ dan $t=20$. Pada indikator selanjutnya yaitu memahami apa yang ditanyakan, siswa menuliskan luas bangun ABCDE sebagai yang ditanyakan.

Pada tahapan merencanakan pemecahan masalah untuk indikator pertama yaitu membuat pemisalan. Siswa menuliskan pemisalan dengan memisalkan alas sebagai $a$ dan tinggi sebagai $t$, serta sisi-sisi yang sejajar pada trapesium yaitu sebagai a dan b. Sedangkan untuk indikator membuat model matematika, siswa membuat model matematika dengan menuliskan rumus trapesium adalah $\frac{1}{2}(a+b) t$ dan rumus segitiga yaitu $\frac{1}{2} a \times t$.

Berdasarkan hasil pekerjaan siswa pada tahapan melaksanakan pemecahan masalah yaitu pada indikator menggunakan model matematika, siswa menggunakan model matematika dengan mensubtitusikan nilai pada setiap sisi-sisi segitiga dan trapesium ke dalam model matematika dan mengoperasikan kedua rumus tersebut, selanjutnya pada indikator menyelesaikan model matematika siswa menjumlahkan nilai luas trapesium dan segitiga yaitu $304+150$ dan menuliskan jawaban akhir yaitu $454 \mathrm{~cm}$.

Sementara itu pada indikator memeriksa kembali jawaban, siswa tidak terlihat memeriksa kembali jawaban yang dikerjakan pada lembar tes, sehingga perlu dilakukan wawancara untuk melengkapi data pada indikator ini, adapun hasil wawancara adalah sebagai berikut.

Peneliti Apakah anda memeriksa kembali jawaban yang anda kerjakan?

Siswa $T \quad Y a$

Peneliti Bagaimana cara anda memeriksa kembali jawaban anda?

Siswa $T$ Dengan mengulangi kembali langkah - langkah yang saya kerjakan

Berdasarkan hasil wawancara di atas dapat disimpulkan bahwa siswa memeriksa kembali jawaban yang dikerjakan.

Pada gambar selanjutnya yaitu hasil jawaban siswa $S$ pada soal faktual yang ditampilkan dalam Gambar 2 berikut ini:

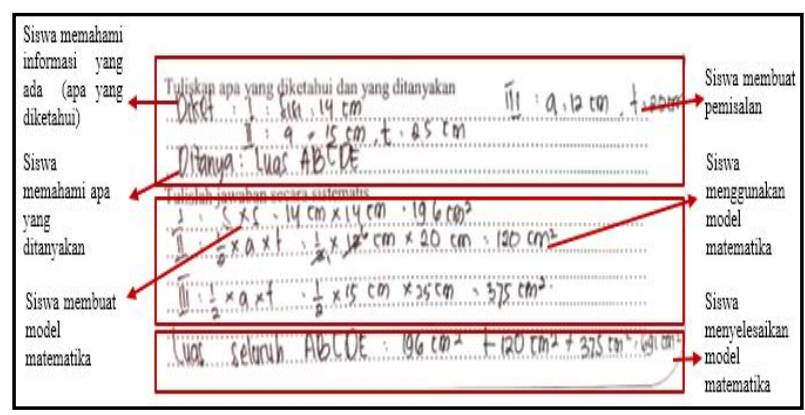

Gambar 2. Jawaban Siswa S Pada Soal Faktual

Pada tahapan memahami masalah untuk indikator memahami informasi yang ada, siswa menuliskan yang diketahui pada bangun pertama adalah sisi $=14 \mathrm{~cm}$, pada bangun kedua $a=15 \mathrm{~cm}$ dan $t=25 \mathrm{~cm}$ dan pada bangun ketiga $a=12 \mathrm{~cm}$ dan $t=20 \mathrm{~cm}$. Sedangkan pada indikator kedua yaitu 
memahami apa yang ditanyakan siswa menuliskan luas ABCDE sebagai apa yang ditanyakan.

Tahapan selanjutnya yaitu merencanakan model matematika, siswa menuliskan alas sebagai $a$ dan tinggi sebagai $t$ pada indikator membuat pemisalan. Kemudian pada indikator menentukan model matematika siswa menuliskan rumus bangun datar yang pertama adalah $s \times s$ dan pada bangun datar kedua dan ketiga adalah $\frac{1}{2} a \times t$.

Berdasarkan hasil pekerjaan siswa pada tahap melaksanakan pemecahan masalah, siswa mensubtitusikan nilai yang ada pada sisi - sisi persegi dan segitiga ke dalam model matematika dan mengoperasikan model matematika tersebut pada indikator menggunakan model matematika. Akantetapi tidak ada bangun datar yang berbentuk persegi. Pada indikator selanjutnya yaitu menyelesaikan model matematika, siswa menjumlahkan nilai bangun datar persegi dan bangun datar segitiga yang pertama serta segitiga yang kedua yaitu $196+120+375=691 \mathrm{~cm}^{2}$.

Pada indikator terakhir yaitu memeriksa kembali jawaban yang dikerjakan, tidak terlihat siswa dalam memeriksa kembali jawaban yang dikerjakan sehingga perlu dilakukan wawancara untuk melengkapi data pada indikator ini, berikut hasil wawancara.

Peneliti Apakah anda memeriksa kembali jawaban yang anda kerjakan?

SiswaS Tidak bu..

Peneliti Mengapa anda tidak memeriksa kembali jawaban anda?

SiswaS Karena menurut saya jawaban saya sudah benar

Merujuk pada hasil wawancara di atas dapat disimpulkan bahwa siswa tidak memeriksa kembali jawaban yang dikerjakan.

Jawaban berikutnya yaitu mengenai soal faktual yang dikerjakan oleh siswa $\mathrm{R}$, yang akan ditampilkan pada Gambar 3 berikut ini:

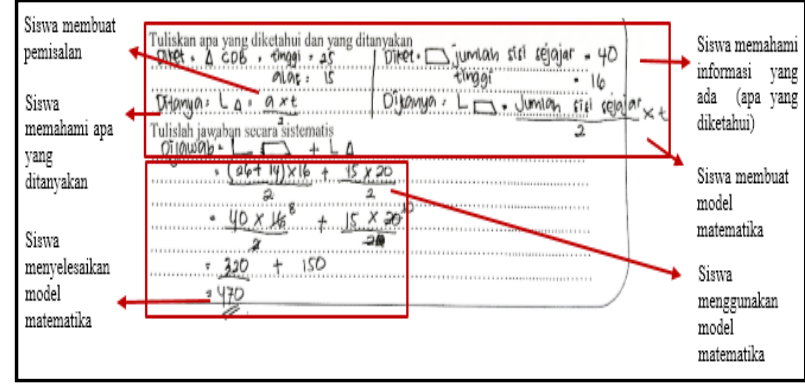

Gambar 3. Jawaban Siswa R Pada Soal Faktual

Pada tahapan memahami masalah untuk indikator memahami informasi yang ada siswa menuliskan bangun pertama adalah segitiga CDB dengan tinggi $=25$ dan alas $=15$. Sedangkan pada bangun kedua yaitu trapesium siswa menuliskan jumlah sisi sejajar $=40$ dan tinggi $=16$. Pada indikator kedua yaitu memahami apa yang ditanyakan siswa menuliskan yang ditanyakan adalah luas segitiga dan luas trapesium.

Sementara itu pada indikator membuat pemisalan, siswa memisalkan alas sebagai $a$ dan tinggi sebagai $t$ dan hal ini dapat terlihat pada rumus bangun datar yang dituliskan siswa yaitu pada segitiga $\frac{a \times t}{2}$ dan trapesium yaitu $\frac{j u m l a h \text { sisi sejajar }}{2} \times t$, pada rumus bangun datar tersebut juga merupakan deskripsi dari indikator menentukan model matematika yang dituliskan oleh siswa.

Memperhatikan hasil kerja siswa pada tahapan melaksanakan pemecahan masalah untuk indikator menggunakan model matematika, siswa mensubtitusikan nilai yang ada pada sisi - sisi trapesium dan segitiga ke dalam model matematika dan mengoperasikannya. Akantetapi pada saat menggunakan model matematika siswa mensubtitusikan nilai sisi - sisi pada segitiga tidak sesuai dengan nilai sisi - sisi segitiga yang dituliskan pada diketahui, sehingga perlu dilakukan 
wawancara untuk menindak lanjuti jawaban siswa dalam menggunakan model matematika, berikut hasil wawancara.

Peneliti Coba anda perhatikan pada diketahui dan langkah yang anda gunakan dalam mengerjakan soal, apakah sudah benar?

Siswa $R \quad$ eeh.. salah

Peneliti Yang mana yang menurut anda yang benar?

Siswa $R \quad$ Benarnya yang saya tulis diketahui

Berdasarkan hasil wawancara dapat disimpulkan bahwa siswa salah dalam mensubtitusikan nilai pada sisi segitiga. Pada indikator selanjutnya yaitu menyelesaikan model matematika, siswa menyelesaikan model matematika dengan cara menjumlahkan luas trapesium dan luas segitiga yaitu $320+150=$ 470.

Pada indikator terakhir yaitu memeriksa kembali jawaban, siswa juga tidak terlihat memeriksa kembali jawaban yang dikerjakan pada lembar tes, sehingga untuk melengkapi data ini perlu dilakukan wawancara. Adapun hasil wawancara dipaparkan sebagai berikut.

$\begin{array}{ll}\text { Peneliti } & \begin{array}{l}\text { Apakah anda memeriksa kembali } \\ \text { jawaban yang anda kerjakan? }\end{array} \\ \text { Siswa } R & \begin{array}{l}\text { Yabu.. } \\ \text { Peneliti }\end{array} \\ & \begin{array}{l}\text { Bagaimana } \\ \text { memeriksanya? }\end{array} \\ \text { Siswa } R & \begin{array}{l}\text { Dengan mengalikan dan membagi } \\ \text { rumusnya }\end{array}\end{array}$

Berdasarkan hasil wawancara dapat disimpulkan bahwa siswa memeriksa kembali jawaban yang dikerjakan. Akantetapi peneliti menemukan ketidak sesuaian antara jawaban siswa dalam mensubtitusikan nilai dari sisi sisi segitiga pada saat menggunakan model matematika dengan nilai sisi - sisi segitiga yang dituliskan siswa $\mathrm{R}$ pada diketahui.

Pada gambar selanjutnya yaitu menunjukkan jawaban siswa $\mathrm{T}$ dalam mengerjakan soal dimensi pengetahuan konseptual. Adapun jawaban siswa di tampilkan pada Gambar 4 berikut:

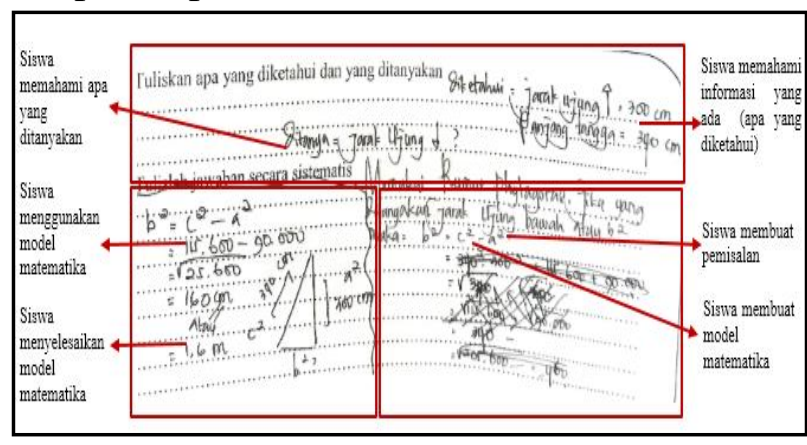

Gambar 4. Jawaban Siswa T Pada Soal Konseptual

Pada indikator memahami informasi yang ada siswa menuliskan jarak ujung atas tangga $300 \mathrm{~cm}$ dan panjang tangga $=340 \mathrm{~cm}$. Pada indikator selanjutnya yaitu memahami apa yang ditanyakan siswa menuliskan jarak ujung bawah tangga ke tembok.

Pada tahapan merencanakan pemecahan masalah untuk indikator pertama yaitu membuat pemisalan. Siswa menuliskan pemisalan dengan memisalkan jarak ujung bawah tangga ke tembok sebagai $b$, panjang tangga sebagai $c$ dan jarak ujung atas tangga ke lantai sebagai $a$. Sedangkan indikator selanjutnya yaitu membuat model matematika, siswa membuat model matematika dengan menuliskan rumus phytagoras $b^{2}=c^{2}-$ $a^{2}$.

Memperhatikan hasil pekerjaan siswa pada tahapan melaksanakan pemecahan masalah yaitu pada indikator menggunakan model matematika, siswa menggunakan model matematika dengan mensubtitusikan nilai yang terdapat pada informasi yang diketahui ke dalam rumus phytagoras dan mengoperasikan rumus tersebut, sementara itu pada indikator menyelesaikan model matematika siswa menuliskan jawaban akhir yaitu $160 \mathrm{~cm}$ atau $1,6 \mathrm{~m}$

Sedangkan pada indikator memeriksa kembali jawaban, siswa tidak terlihat 
memeriksa kembali jawaban yang dikerjakan pada lembar tes, sehingga perlu dilakukan wawancara untuk melengkapi data pada indikator ini, adapun hasil wawancara adalah sebagai berikut.

\begin{tabular}{ll}
\hline Peneliti & $\begin{array}{l}\text { Apakah anda memeriksa kembali } \\
\text { jawaban yang anda kerjakan? }\end{array}$ \\
Siswa $T$ & Ya \\
Peneliti & Bagaimana caranya? \\
Siswa $T$ & $\begin{array}{l}\text { Menghitungnya kembali dengan } \\
\text { cara yang sama }\end{array}$
\end{tabular}

Berdasarkan hasil wawancara di atas dapat disimpulkan bahwa siswa memeriksa kembali jawaban yang dikerjakan yaitu dengan menghitung kembali jawaban yang dikerjakan.

Pada gambar selanjutnya yaitu mengenai jawaban siswa $S$ pada soal konseptual yang dijelaskan pada Gambar 5 berikut:

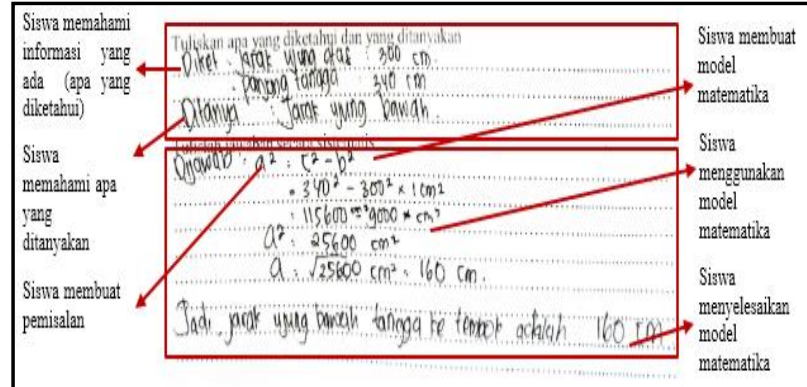

Pada tanapan memanamı masaran untuk indikator mér Jawaban Siswa S Pada Soal Konsentual siswa menuliskan yang diketahui jarak ujung atas = $300 \mathrm{~cm}$ dan panjang tangga $340 \mathrm{~cm}$. Sedangkan pada indikator kedua yaitu memahami apa yang ditanyakan siswa menuliskan jarak ujung bawah.

Pada tahapan selanjutnya yaitu merencanakan model matematika, siswa memisalkan jarak ujung bawah tangga ke tembok sebagai $a$, panjang tangga sebagai $c$ dan jarak ujung atas tangga ke lantai sebagai $b$ pada indikator membuat pemisalan. Kemudian pada indikator menentukan model matematika siswa menuliskan rumus phytagoras yaitu $a^{2}=$ $c^{2}-b^{2}$.
Berdasarkan hasil pekerjaan siswa pada tahap melaksanakan pemecahan masalah, siswa mensubtitusikan nilai yang ada pada informasi yang diketahui ke dalam model matematika dan mengoperasikan model matematika tersebut pada indikator menggunakan model matematika. Sementara itu siswa menuliskan $\mathrm{cm}^{2}$ dalam mengerjakan model matematika, padahal ini adalah soal untuk menentukan sisi terpendek pada phytagoras bukan menentukan luas bangun datar. Sedangkan untuk indikator selanjutnya yaitu menyelesaikan model matematika, siswa menuliskan hasil akhir jawaban yaitu $160 \mathrm{~cm}$.

Pada indikator terakhir yaitu memeriksa kembali jawaban yang dikerjakan, tidak terlihat siswa dalam memeriksa kembali jawaban yang dikerjakan, s ehingga perlu dilakukan wawancara untuk melengkapi data pada indikator ini, berikut hasil wawancara.

Peneliti Apakah anda memeriksa kembali jawaban yang anda kerjakan?

Siswa $S \quad Y a$

Peneliti Bagaimana cara anda memeriksa kembali jawaban anda?

\section{Siswa S Dengan menghitung kembali}

Merujuk pada hasil wawancara di atas dapat disimpulkan bahwa siswa memeriksa kembali jawaban yang dikerjakan dengan cara menghitung kembali.

Gambar selanjutnya yaitu jawaban siswa $\mathrm{R}$ pada soal konseptual yang dijelaskan pada Gambar 6 berikut:

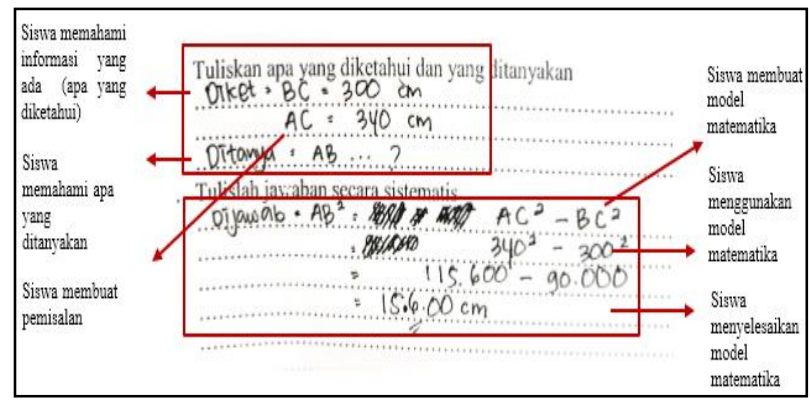

Gambar 6. Jawaban Siswa R Pada Soal Konseptual 
Pada tahapan memahami masalah untuk indikator memahami informasi yang ada siswa menuliskan yang diketahui $\mathrm{BC}=300 \mathrm{~cm}, \mathrm{AC}=$ $340 \mathrm{~cm}$. Pada indikator kedua yaitu memahami apa yang ditanyakan siswa menuliskan yang ditanyakan $=\mathrm{AB}$.

Sementara itu pada indikator membuat pemisalan, siswa memisalkan BC sebagai jarak ujung atas tangga ke lantai, AC sebagai panjang tangga dan $\mathrm{AB}$ sebagai jarak ujung bawah tangga ke tembok. Selanjutnya pada indikator menentukan model matematika siswa menuliskan rumus $A B^{2}=A C^{2}-B C^{2}$ untuk mencari nilai sisi terpendek pada phytagoras.

Pada tahapan melaksanakan pemecahan masalah untuk indikator menggunakan model matematika, siswa mensubtitusikan nilai yang ada pada informasi yang diketahui dan mengoperasikannya. Akantetapi pada indikator selanjutnya yaitu menyelesaikan model matematika cicu/a menulickan iax/ahan akhir ada Gambar 7. Jawaban Siswa T Pada Soal Prosedural il akhirnya karena siswa tidak mengakarkan hasil dari nilai yang dioperasikan siswa pada saat mengerjakan model matematika.

Pada indikator memeriksa kembali jawaban, tidak terlihat siswa memeriksa kembali jawaban yang dikerjakan pada lembar tes, sehingga untuk melengkapi data ini perlu dilakukan wawancara.

Adapun hasil wawancara dipaparkan sebagai berikut.

Peneliti Apakah menurut anda jawaban $15.600 \mathrm{~cm}$ itu adalah hasil

Siswa $R$ akhirnya?

Peneliti $Y a$

Apakah anda memeriksa kembali

Siswa $R$ jawaban yang anda kerjakan?

Peneliti $\quad Y a$

Bagaimana cara anda memeriksa

Siswa $R$ kembali jawaban anda?

Dengan cara 115.600 - 90.00

hasilnya 15.600
Berdasarkan hasil wawancara dapat disimpulkan bahwa siswa memeriksa kembali jawaban yang dikerjakan. Akantetapi siswa menyebutkan bahwa hasil akhir dari jawaban yang dikerjakan adalah 15.600, padahal itu bukan hasil akhirnya.

Gambar selanjutnya yaitu mengenai jawaban siswa $\mathrm{T}$ pada indikator pemecahan masalah pada soal prosedural yang dijelaskan pada Gambar 7 berikut:

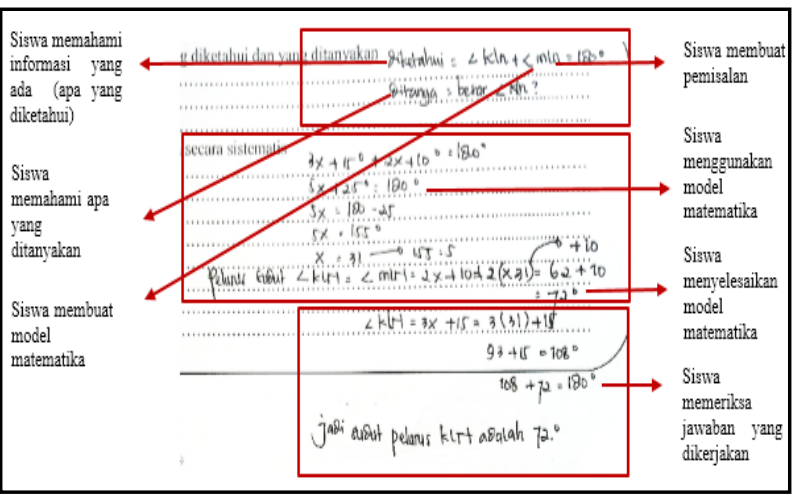

Pada indikator memahami informasi yang ada siswa menuliskan sudut KLN + sudut $\quad$ MLN $=180^{\circ}$. Sedangkan untuk indikator memahami apa yang ditanyakan siswa menuliskan besar sudut KLN.

Pada tahap merencanakan pemecahan masalah pada indikator pertama yaitu membuat pemisalan. Siswa membuat pemisalan dengan menulis sudut yang terdapat pada gambar sebagai $<$ KLN dan $<$ MLN. Sementara itu, pada indikator membuat model matematika, siswa membuat model matematika seperti yang ditulis pada informasi yang diketahui yaitu < $\mathrm{KLN}+<\mathrm{MLN}=180^{\circ}$.

Pada hasil pekerjaan siswa pada tahapan melaksanakan pemecahan masalah yaitu pada indikator menggunakan model matematika, siswa menggunakan model matematika dengan mensubtitusikan $<\mathrm{KLN}$ dengan $3 x+15^{\circ}+2 x+10^{\circ}=180^{\circ}$ kemudian mengoperasikan model matematika tersebut sampai menemukan nilai $x$ yaitu $31^{\circ}$. 
Sedangkan untuk indikator selanjutnya yaitu menyelesaikan model matematika siswa menuliskan jawaban akhir dalam menemukan besar pelurus sudut KLN yaitu sudut MLN = $72^{\circ}$.

Sementara itu pada indikator memeriksa kembali jawaban, siswa terlihat memeriksa kembali jawaban yang dikerjakan pada lembar tes dengan cara mencari besar sudut MLN yaitu $108^{\circ}$. Kemudian menjumlahkan kedua sudut yaitu $108^{\circ}+72^{\circ}=$ $180^{\circ}$.

Pada gambar selanjutnya yaitu tentang jawaban siswa $S$ pada soal prosedural yang dijelaskan pada Gambar 8 berikut:

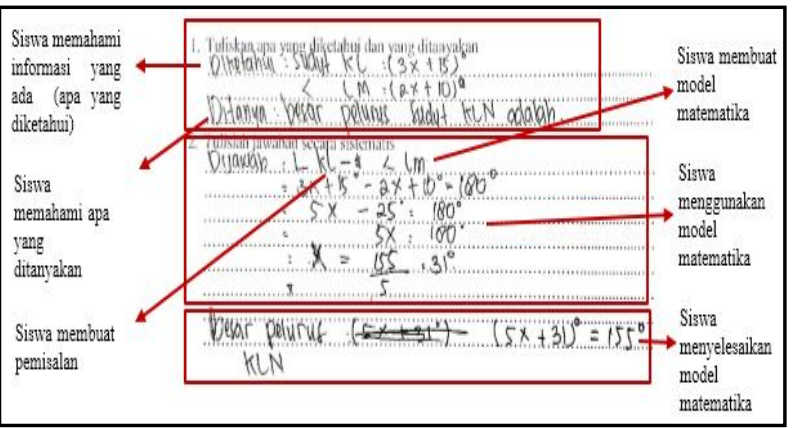

Pada tahapan memahami masalah untuk indikator memahami informasi yang ada, siswa menuliskan yang diketahui sudut $\mathrm{KL}=(3 x+$ $15)^{\mathrm{o}}$ dan sudut $\mathrm{LM}=(2 x+10)^{\mathrm{o}}$. Sedangkan pada indikator kedua yaitu memahami apa yang ditanyakan siswa menuliskan besar pelurus sudut KLN adalah.

Pada tahapan selanjutnya yaitu merencanakan model matematika untuk indikator membuat pemisalan, siswa membuat pemisalan dengan menulis sudut yang terdapat pada gambar sebagai $<\mathrm{KL}$ dan $<\mathrm{LM}$. Kemudian pada indikator menentukan model matematika siswa menuliskan rumus $<\mathrm{KL}-<$ LM.

Berdasarkan hasil pekerjaan siswa pada tahap melaksanakan pemecahan masalah untuk indikator menggunakan model matematika, siswa mensubtitusikan nilai yang ada pada informasi yang diketahui ke dalam model matematika sebagai berikut: $3 x+15^{\circ}-2 x+10^{\circ}$ $=180^{\circ}$, kemudian siswa mengoperasikan model matematika tersebut sehingga menemukan nilai $x$ yaitu $31^{\circ}$. Pada indikator selanjutnya yaitu menyelesaikan model matematika, siswa menuliskan hasil akhir jawaban yaitu $155^{\circ}$, padahal itu bukan merupakan hasil akhirnya sehingga perlu dilakukan wawancara untuk melengkapi data ini. Adapun hasil wawancara adalah sebagai berikut.

\begin{tabular}{|c|c|}
\hline Peneliti & $\begin{array}{l}\text { Apakah } 155^{\circ} \text { merupakan hasil akhir } \\
\text { dari jawaban anda? }\end{array}$ \\
\hline Siswa $S$ & Tidak \\
\hline Peneliti & Mengapa anda \\
\hline Siswa $S$ & menyelesaikannya? \\
\hline Peneliti & mmm...saya ragu \\
\hline$S$ & Dari \\
\hline Peneliti & lasilnya \\
\hline Bis & $\begin{array}{l}\text { ah anda merasa ada cara lain } \\
\text { mengerjakan soal tersebut? }\end{array}$ \\
\hline Peneliti & $Y a$ \\
\hline Sisv Gan & $\begin{array}{l}\text { anda hisa menoeriakan soal } \\
\text { pan Siswa S Pada Soal Prosedural }\end{array}$ \\
\hline Peneliti & Tidak \\
\hline Siswa $S$ & $\begin{array}{l}\text { Apakah anda memeriksa kembal } \\
\text { jawaban yang anda kerjakan? } \\
\text { Tidak }\end{array}$ \\
\hline
\end{tabular}

Berdasarkan hasil wawancara di atas dapat disimpulkan bahwa jawaban $155^{\circ}$ bukan merupakan hasil akhirnya, hal ini karena siswa ragu dengan hasil pekerjaannya, selain itu siswa juga tidak memeriksa kembali jawaban yang dikerjakan sehingga tidak memenuhi indikator memeriksa kembali jawaban.

Pada gambar selanjutnya yaitu tentang jawaban siswa $\mathrm{R}$ pada soal prosedural yang dijelaskan pada Gambar 9 berikut: 


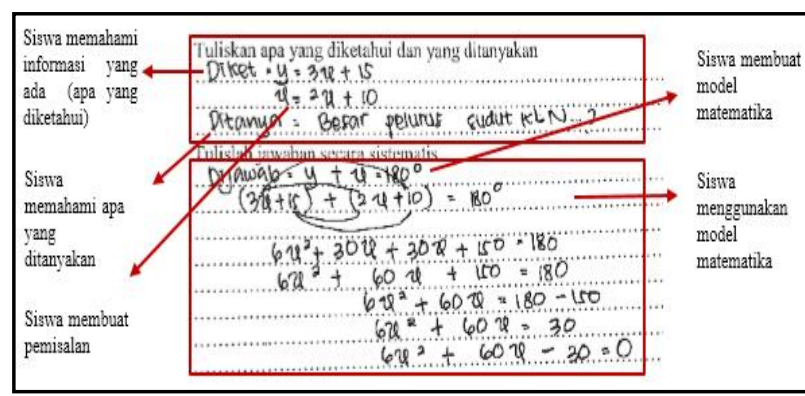

Pada tahapan memahami masalah untuk indikator memahami informasi yang ada siswa menuliskan yang diketahui $y=3 x+15$ dan $x=$ $2 x+10$. Pada indikator kedua yaitu memahami apa yang ditanyakan siswa menuliskan besar pelurus sudut KLN.

Pada indikator membuat pemisalan, siswa memisalkan $y$ sebagai $<$ KLN yaitu $3 x+$ 15 dan $x$ sebagai $<$ MLN yaitu $2 x+10$. Pada indikator selanjutnya yaitu menentukan model matematika siswa menuliskan $y+x=180^{\circ}$.

Memperhatikan hasil pekerjaan siswa pada tahapan melaksanakan pemecahan masalah untuk indikator menggunakan model matematika, siswa mensubtitusikan nilai yang ada pada informasi yang diketahui dan mengoperasikannya dengan cara mengalikan $3 x$ dengan $2 x$ dan 10 kemudian mengalikan 15 dengan $2 x$ dan 10 . Kemudian pada indikator menyelesaikan model matematika tidak terlihat siswa menuliskan jawaban akhir dalam menemukan besar pelurus sudut KLN.

Sementara itu pada indikator memeriksa kembali jawaban, tidak terlihat siswa memeriksa kembali jawaban yang dikerjakan pada lembar tes, sehingga perlu dilakukan wawancara untuk melengkapi data ini. Adapun hasil wawancara adalah sebagai berikut.

\begin{tabular}{|c|c|}
\hline Peneliti & $\begin{array}{l}\text { Apakah anda menemukan hasil } \\
\text { akhir dari jawaban anda? }\end{array}$ \\
\hline Siswa $R$ & $Y a$ \\
\hline Peneliti & Berapakah hasil akhirnya? \\
\hline Siswa $R$ & Ini bu.. $6 x^{2}+60 x-30=0$ \\
\hline Peneliti & $\begin{array}{l}\text { Apakah itu adalah hasil yang } \\
\text { ditanyakan pada soal? }\end{array}$ \\
\hline Siswa $R$ & $Y a$ \\
\hline Penı Gam & $\begin{array}{l}\text { ar 9. Jawaban Siswa R Pada Soal Prosedural } \\
\text { jawaban yang anda kerjakan! }\end{array}$ \\
\hline Siswa $R$ & $Y a$ \\
\hline Peneliti & $\begin{array}{l}\text { Bagaimana cara anda memeriksa } \\
\text { kembali jawaban anda? }\end{array}$ \\
\hline Siswa $R$ & Dengan menambahkannya \\
\hline Peneliti & Apa yang anda tambahkan? \\
\hline Siswa $R$ & $\begin{array}{l}\text { Ini bu..dari } 6 x^{2}+30 x+30 x+150 \\
=180 \text { sampai seterusnya }\end{array}$ \\
\hline
\end{tabular}

Berdasarkan hasil wawancara di atas dapat disimpulkan bahwa siswa menganggap ia sudah menuliskan jawaban akhir sesuai seperti yang diminta pada soal yaitu $6 x^{2}+60 x-$ $30=0$ dan siswa juga mengatakan bahwa ia memeriksa kembali jawaban yang dikerjakan dengan cara menambahkannya. Padahal jika dilihat pada apa yang ditanyakan pada soal siswa belum menyelesaikan jawaban tersebut karena siswa tidak menuliskan nilai dari besar pelurus sudut KLN.

Hasil penelitian mengenai pemecahan masalah siswa pada tahap memahami masalah menunjukkan sebagian besar siswa menentukan informasi yang diketahui dan ditanyakan pada soal, hal ini diperkuat dengan pernyataan Fimatesa, Fitrani \& Suherman (2014) bahwa dalam memahami masalah, siswa diharapkan mampu untuk dapat mengidentifikasi unsur-unsur yang diketahui, ditanyakan dan kecukupan unsur yang diperlukan.

Pada tahapan merencanakan pemecahan masalah yang dilakukan siswa pada indikator membuat pemisalan menunjukkan keberagaman siswa dalam memisalkan data 
atau informasi yang diperoleh sebelum siswa menjawab soal, hal ini untuk mempermudah siswa dalam menentukan model matematika.

Hal ini juga sejalan dengan penelitian yang dilakukan Tambunan (2014) bahwa membuat pemisalan akan mempermudah dalam merencanakan model matematika yang akan digunakan untuk memecahkan suatu masalah, karena tujuan utama dalam merencanakan pemecahan suatu masalah adalah menentukan model pemecahan masalah yang sesuai dengan masalah yang akan diselesaikan.

Pada tahapan melaksanakan pemecahan masalah untuk indikator menggunakan model matematika dan menyelesaikan model matematika, sebagian besar siswa tidak tepat dalam mengoperasikan model matematika sehingga berdampak pada penyelesaian model matematika. Hal ini diperkuat dengan penelitian yang dilakukan Yarmayani (2014) bahwa perhitungan dengan tepat akan mendapatkan hasil penyelesaian soal dengan baik.

Pada indikator terakhir yaitu memeriksa kembali jawaban, hampir seluruh siswa tidak terlihat dalam memeriksa jawaban yang dikerjakan pada lembar tes sehingga dalam hal ini perlu dilakukan wawancara dan hasil wawancara menunjukkan siswa memeriksa kembali jawaban, namun terdapat juga soal dimana siswa tidak memeriksa kembali jawaban karena siswa ragu dengan jawaban yang dikerjakan. Selain itu terdapat siswa yang berpendapat bahwa ia tidak perlu memeriksa kembali jawaban karena sudah yakin dengan jawaban yang dikerjakan. Padahal memeriksa kembali jawaban sangat penting karena dapat memastikan langkah yang kita kerjakan adalah benar. Hal ini sejalan dengan pendapat Riskayani, Wherdiana \& Hatibe (2017) bahwa suatu penyelesaian penting diperiksa kembali, hal ini untuk mengetahui apakah langkahlangkah dalam menyelesaikan itu sudah benar dan apakah hasil yang diperoleh itu sesuai dengan yang diminta dalam soal.

Pada siswa yang berkemampuan tinggi memenuhi indikator pemecahan masalah dengan memahami apa yang diketahui dan ditanyakan pada soal, serta membuat pemisalan dan menentukan model matematika, siswa juga menggunakan model matematika dan menyelesaikan model matematika. Selain itu siswa memeriksa kembali jawaban yang dikerjakan meskipun tidak terlihat pada lembar tes dan harus dilengkapi dengan hasil wawancara. Hal ini sejalan dengan penelitian yang dilakukan oleh Nawangsari (2012) menyatakan bahwa siswa berkemampuan matematika tinggi memahami masalah dengan menuliskan apa yang diketahui dan apa yang ditanyakan dari soal, membuat rencana untuk menyelesaikan soal, melaksanakan rencana secara terurut, langkah demi langkah dan memeriksa kembali jawaban dengan cara menghitung kembali langkah - langkah yang telah dikerjakan.

Pada siswa yang berkemampuan sedang, terdapat beberapa indikator pemecahan masalah yang tidak terpenuhi. Siswa memahami informasi yang terdapat pada soal dengan menuliskan apa yang diketahui, yang ditanyakan dan membuat pemisalan. Akantetapi siswa kurang memahami model matematika apa yang digunakan dalam menyelesaikan soal, sehingga siswa salah dalam menentukan model matematika. Selain itu pada saat menggunakan model matematika dan menyelesaikan model matematika terdapat kesalahan dalam melakukan pengoperasian dan tidak setiap soal siswa melakukan pemeriksaan kembali pada hasil jawaban yang dikerjakan. Hal ini sejalan dengan penelitian yang dilakukan oleh Nirmalitasari (2012) bahwa siswa berkemampuan sedang merupakan kategori cukup dalam pemecahan masalah. Terlihat bahwa siswa termasuk pada kategori cukup pada tahap memahami masalah, 
merencanakan strategi penyelesaian, melakukan rencana penyelesaian, namun pada kategori melihat kembali penyelesaian masalah masuk dalam kategori kurang.

Pada siswa berkemampuan rendah menunjukkan bahwa siswa tidak menuliskan yang diketahui sesuai dengan yang tertera pada soal, pada saat siswa menentukan dan menggunakan model matematika, langkah yang dilakukan tidak jelas dan tidak sesuai dengan perintah soal dan terdapat kesalahan dalam pengoperasian. Selain itu siswa hanya sekedar mempunyai hasil penyelesaian tanpa memeriksa kembali langkah pengerjaannya secara keseluruhan dan hanya melakukan pengecekan pada hasil akhir saja. Hal ini sejalan dengan penelitian yang dilakukan oleh Sari (2012) bahwa siswa berkemampuan rendah merupakan kategori kurang dalam pemecahan masalah. Hal ini ditunjukkan dari kemampuan siswa dalam tahap memahami masalah, merencanakan strategi penyelesaian, melakukan rencana penyelesaian dan melihat kembali penyelesaian masalah.

\section{SIMPULAN}

Adapun kesimpulan pada penelitian ini adalah sebagai berikut:

1. Pemecahan masalah siswa pada soal faktual menunjukkan jawaban siswa yang berkemampuan tinggi, sedang dan rendah memenuhi hampir seluruh indikator kecuali indikator memeriksa kembali jawaban.

2. Pemecahan masalah siswa pada soal konseptual menunjukkan jawaban siswa yang berkemampuan tinggi, sedang dan rendah memenuhi seluruh indikator pemecahan masalah

3. Pemecahan masalah siswa pada soal prosedural menunjukkan jawaban siswa yang berkemampuan tinggi, sedang dan rendah yang tidak memenuhi beberapa indikator yaitu pada indikator menyelesaikan soal dan indikator memeriksa kembali jawaban.

\section{UCAPAN TERIMAKASIH}

Syukur Alhamdulillah peneliti panjatkan atas kehadiran Allah SWT, Yang memiliki keistimewaan dan pemberian segala kenikmatan besar, baik nikmat iman, kesehatan dan kekuatan didalam melakukan penelitian ini. Selawat dan salam senantiasa tercurahkan kepada Sayyidina Muhammad SAW. Pada kesempatan ini peneliti menyampaikan rasa terimakasih kepada

1. Institut Teknologi Batam yang telah memberi kesempatan untuk melakukan penelitian, dan

2. MTs NU TMI Pujon yang telah memberi peneliti izin untuk melakukan penelitian disekolah tersebut

Semoga penelitian ini memberikan manfaat untuk semua orang.

\section{DAFTAR PUSTAKA}

Fatmawati, H., Mardiyana \& Triyanto. (2014). Analisis Berpikir Kritis Siswa Dalam Pemecahan Masalah Matematika Berdasarkan Polya Pada Pokok Bahasan Persamaan Kuadrat. Jurnal Elektronik Pembelajaran Matematika, 2(9)

Haryani, D. (2012). Profil Berpikir Kritis Siswa SMA dengan Gaya Kognitif Field Independent dan Berjenis Laki-Laki dalam Memecahkan Masalah Matematika. Prosiding SNMPM Universitas Sebelas Maret

Kemendikbud. (2013). Materi Pelatihan Guru Implementasi Kurikulum 2013. Jakarta: Badan Pengembangan Sumber Daya Manusia dan Penjaminan Mutu Pendidikan. Jakarta.

Ersoy, E \& Guner, P. (2012). Mathematics Teaching And Mathematical Thinking. Journal of Research in Education and Teaching. ISSN: 2146-9199 
Das, R \& Das, G.C. (2013). Match Anxiety The Poor Problem Solving Factor in School Mathematic. International Journal of scientific and Research Publication, 3(4): 1-5

Kemendikbud. (2019). Konferensi Pers UN 2017 Jenjang SMP UN Untuk Memantau, Mendorong dan Meningkatkan Mutu Pembelajaran. Jakarta.

Desvika, Dian dan Budiyono. (2015). Aspek Kognitif Taksonomi Bloom Dalam Soal Ujian Nasional Matematika SMP Tahun Pelajaran 2013/2014. EKUIVALEN, 18(2)

Marzuqi, A.A., Sugiarti, T \& Setiawan, T.B. (2015). Analisis Deskriptif Soal Ujian Nasional Matematika Tingkat Sekolah Menengah Pertama Tahun Ajaran 2012/2013 dan 2013/2014 Berdasarkan Taksonomi Bloom Revisi. Artikel Ilmiah Mahasiswa. Universitas Negeri Jember. Jember

Oktorizal, Elniati, S \& Suherman. (2012). Peningkatan Level Berpikir Siswa Pada Pembelajaran Geometri dengan Pendekatan Pendidikan Matematika Realistik. Jurnal Pendidikan Matematika, 1(1)

Fimatesa, W., Fitrani, D \& Suherman. (2014). Meningkatkan Kemampuan Pemecahan Masalah Matematika Siswa Kelas VIII SMPN 8 Padang Tahun Pelajaran 2013/2014 Dengan Menggunakan Strategi Pembelajaran Inkuiri. Jurnal Pendidikan Matematika, 3(2): 25-28

Tambunan, H. (2014). Strategi Heuristik Dalam Pemecahan Masalah Matematika Sekolah. Jurnal Saintech, 6(4)

Yarmayani, A. (2014). Analisis Kemampuan Pemecahan Masalah Matematis Siswa Kelas XI MIPA SMA Negeri 1 Kota Jambi. Jurnal Ilmiah DIKDAYA
Riskayani, Werdhiana, I.K \& Hatibe, A. (2017). Penerapan Problem Solving Menggunakan Strategi Heuristik Terhadap Pemahaman Konsep Tentang Kalor Pada Siswa Kelas X SMA Negeri 4 Palu. Jurnal Pendidikan Fisika Tadulako, 5(2)

Nawangsari, T. (2012). Profil Pemecahan Masalah Trigonometri Siswa SMA Ditinjau Dari Kemampuan Matematika. Dokumen Karya Ilmiah. Unirow, 12 Februari 2012

Nirmalitasari, O.S. (2012). Profil Kemampuan Siswa dalam Memecahkan Masalah Matematika Berbentuk Open-Start Pada Materi Bangun Datar. MATHEdunesa, 1(1)

Sari, Y.M. (2012). Profil Kemampuan Siswa SMP Dalam Memecahkan Masalah Matematika Open-Ended Materi Pecahan Berdasarkan Tingkat Kemampuan Matematika. MATHEdunesa, 1(1)

Polya, George. (1973). How to Solve It - A New Aspect of Mathematical Method (Second edition). New Jersey: Princeton University Press

Bloom, B.S. (1956). Taxonomy of Educational Objectives. Canada: DavidMcKay Company, Inc

Nursyahidah, Farida., Bagus \& Yana. (2018). Students Problem Solving Ability Based on Realistic Mathematics with Ethnomathematics. Journal of Research and Advances in Mathematics Education. ISSN: 2503-3697

Hidayat, Wahyu \& R. Sariningsih. (2018). Kemampuan Pemecahan Masalah Matematis Dan Adversity Quotient Siswa SMP Melalui Pembelajaran Open Ended. Jurnal Nasional Pendidikan

Matematika. 2 (1) 